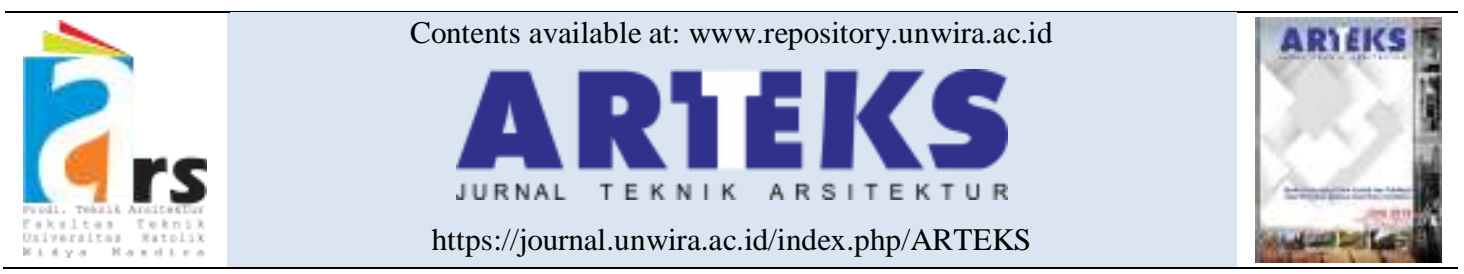

Research paper

doi: $10.30822 /$ arteks.v6i2.757

\title{
Biophilic design patterns and local knowledge of plants application in Baba-Nyonya heritage shophouses' courtyard
}

\author{
Azizi Bahauddin $^{1 *}$, Rani Prihatmanti ${ }^{2} \mathbb{D}$, Josephine Ong ${ }^{3 / \mathbb{C}}$ \\ ${ }^{1,3}$ Interior Architecture Programme, School of Housing, Building and Planning, \\ Universiti Sains Malaysia, Penang, Malaysia \\ ${ }^{2}$ Interior Architecture Department, School of Creative Industry, \\ Universitas Ciputra Surabaya, Indonesia
}

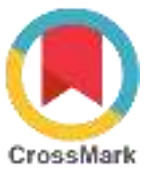

\begin{tabular}{|c|c|}
\hline ARTICLE INFO & ABSTRACT \\
\hline $\begin{array}{l}\text { Article history: } \\
\text { Received November } 29,2020 \\
\text { Received in revised form Dec. 06, } 2020 \\
\text { Accepted January } 21,2021 \\
\text { Available online August } 01,2021 \\
\end{array}$ & $\begin{array}{l}\text { Biophilic design is a well-known design philosophy based on human- } \\
\text { nature relationships. However, it has not been explored extensively } \\
\text { in the Malaysian context and most of the previous studies were based } \\
\text { on plants which were not suitable for tropical climate. This paper } \\
\text { analyses the application of biophilic design and the usage of local }\end{array}$ \\
\hline $\begin{array}{l}\text { *Corresponding author: Azizi Bahauddin } \\
\text { Interior Architecture Programme, School of } \\
\text { Housing, Building and Planning } \\
\text { Universiti Sains Malaysia } \\
\text { Email: azizigt@ gmail.com } \\
\text { ORCID: https://orcid.org/0000-0002-0050- } \\
7499\end{array}$ & $\begin{array}{l}\text { edible and medicinal plants in Baba-Nyonya heritage shophouses' } \\
\text { courtyards in George Town UNESCO World Heritage Site, Penang, } \\
\text { Malaysia. The aim of this research is to enhance the human quality } \\
\text { of life through biophilic design with local knowledge application in } \\
\text { the urban setting. Qualitative method strategies were applied to } \\
\text { collect the data: photographic survey, plant inventory and building } \\
\text { observation. Three heritage shophouses that had been adaptively } \\
\text { reused into contemporary cafes were selected for this study. } \\
\text { Significant results showed that Biophilic Design Pattern under the } \\
\text { visual connection with nature (P1)' has been achieved through the } \\
\text { application of edible and medicinal plants. Unfortunately, the local } \\
\text { knowledge for applying edible and medicinal plants for achieving } \\
\text { biophilic design compliance is weak. In the future, a further study is } \\
\text { needed to identify the species of local edible and medicinal plants } \\
\text { which can be applied in the Baba-Nyonya heritage shophouses } \\
\text { courtyards. }\end{array}$ \\
\hline
\end{tabular}

\section{Introduction}

Recently, most of the traditional Baba-Nyonya shophouses in the UNESCO World Heritage Site (WHS) in George Town, Penang are being altered and refurbished to suit new purposes of the exterior and the interior of these properties. Courtyard, which is located at the centre of the shophouse, could be considered as the 'heart' of the building due to its cultural, climatic, and psychological significances. It is a multi-purpose semi-outdoor space where the daylight can penetrate and exposed to the outdoor air. Despite of its long and narrow rectangular form, shophouses were purposely built to be climatically comfortable with the presence of the courtyard. However, the current usage of air conditioner has altered the original courtyard purposes. Furthermore, the opening on top of the courtyard was intentionally covered with the translucent polycarbonate sheet to prevent the cool air dissipating from the building, to prevent the rainwater from entering the building, and as a safety measure. By covering the courtyard's opening, shophouse has become a tight building. According to (Burchett, Torpy, and Tarran 2008), human spend $90 \%$ of the time in indoor built environment. Indoor air quality has become more polluted compared to the outdoor air. Moreover, a building that has undergone changes from its 
original purpose could create a problematic condition to the building occupants. This condition will reduce the building occupants' well-being and their productivities due to the poor quality of the indoor environment, particularly the indoor air (Prihatmanti and Bahauddin 2014). Piko (2006) also agreed that the indoor environment is an essential determinant of human well-being. Therefore, human well-being is a concern in the indoor environment of these heritage shophouses.

There is sufficient evidence being highlighted focusing on the visual connection with indoor plants promoting a better health psychologically, physiologically, and cognitively. The relationship between human and nature is crucial to reestablish a built environment that is conducive to the human health; known as 'biophilic design' (Kellert 2008). Apparently, the previous studies were based only on ornamental plants and conducted in contemporary buildings: in a greenhouse (Lee et al. 2015), in an indoor office (Jumeno and Matsumoto 2015), in a reverberation chamber of a university (Asdrubali et al. 2014; D’Alessandro, Asdrubali, and Mencarelli 2015), and many others. In Malaysia, the use of Malay local knowledge in edible and medicinal plants can be found in villages and smaller rural towns. Nevertheless, there are limited studies conducted regarding planting edible and medicinal plants in Baba-Nyonya heritage shophouses, namely the courtyard areas. With exposures to daylight and outdoor air, this area has potential to be an indoor green space that is integrated with the building. Having greeneries in the building will be beneficial to the occupants. Therefore, the aim of this paper is to examine the application of local edible and medicinal plants based on the Biophilic Design Patterns and Baba-Nyonya local knowledge in heritage shophouses' courtyards.

Humans are biologically well adapted to the natural environment and obtain basic physical and emotional needs from the natural environment that is essential for human survival and wellbeing. Humans also depend on nature to seek protection from predators, weather, and nutritional food sources (Orians and Heerwagen 1992); and their behaviours evolved and shaped through their natural environment. The concept of 'biophilia' describes humans to having innate tendency to focus on life and life-like processes (Wilson 1984); strengthened by the local knowledge understanding in a concept of claiming that humans need nature at physical level for spiritual, aesthetical, intellectual, and cultural needs.

Biophilic design definition

The Biophilic Design contains the 'organic or naturalistic' and the 'place-based or vernacular' dimensions (Karima, Firzal, and Faisal 2020). The organic dimension is defined as the forms and shapes in the built-up environment that directly, indirectly, and symbolically reflect human innate attraction by nature (Widodo 2019). On the other hand, 'vernacular dimension' refers to the built environment that is reflecting the culture and ecology of a locality or geographic area. Kellert (2008) implementing biophilia concept into the design of built environment in order to re-join the relationships between human and nature is known as Biophilic Design. Ryan et al. (2014) established the 14 Biophilic Design Patterns and categorised it into three: Nature in the space, natural analog, and nature of the space (table 1).

Table 1. The 14 biophilic design patterns

\begin{tabular}{ll}
\hline Categories & Biophilic Design Patterns \\
\hline & P1. Visual Connection with Nature \\
& P2. Non-Visual Connection with Nature \\
Nature in & P3. Non-Rhythmic Sensory Stimuli \\
the Space & $\begin{array}{l}\text { P4. Thermal and Airflow Variability } \\
\end{array}$ \\
& $\begin{array}{l}\text { P5. Presence of Water } \\
\text { P6. Dynamic \& Diffuse Light }\end{array}$ \\
& P7. Connection with Natural System \\
\hline \multirow{2}{*}{ Natural } & P8. Biomorphic Forms and Patterns \\
Analogs & P9. Material Connection with Nature \\
\hline \multirow{3}{*}{ Nature of } & P10. Complexity and Order \\
the Space & P11. Prospect \\
& P13. Refuge \\
& P14. Risk/Peril
\end{tabular}

Source: (Ryan et al. 2014)

There were a number of studies proving that the presence of nature in built environment can enrich human well-being such as in reducing stress (Bringslimark, Hartig, and Patil 2007; Ulrich et al. 1991); improving cognition (Lohr 2010); positive mood and task performance (Shibata and Suzuki 2004; Larsen et al. 1998) and reducing discomfort symptoms such as coughing, dry skin, and eye irritation (Fjeld and Bonnevie 2002). Ryan et al. (2014) stated that Biophilic Design Pattern 1 (P1) which is the 'visual connection with nature' refers to human sight connection with natural elements application such as foliage plants, flowers, water feature, and animals in man-made environment. Thus, plants are continuously brought into the indoor 
environments in private and commercial spaces for their aesthetics and cultural values, edibility and medicinal purposes.

\section{Baba-Nyonya local knowledge}

Based on the Baba-Nyonya local knowledge, plants are used as natural resources for food and beverages, flavourings, medicine and poison, essential oils, aromatherapy, and ritual and ceremonial materials (Samy, Sugumaran, and Lee 2014; Leipzig 1996). The usage of a wide variety of edible plants in Malaysia were recorded among the indigenous people of Peninsular Malaysia (C. H., A., and M. 2012). Today, the local knowledge of edible native plants is still being applied by urban people in their compounds such as courtyard, balcony, and indoor kitchen (Salleh, Rashid, and Sakip 2016; Milow et al. 2014; C. H., A., and M. 2012). According to Prihatmanti and Taib (2018), growing plants in the semi-outdoor space is possible to be conducted due to its climatic condition. In a semi-outdoor environment, the daylight intensity is significantly reduced compare to the outdoor environment. Daylight is essential for the metabolic process of plants which will affect the growth performance. Therefore, shade-loving plants are suitable to be grown in place with limited amount of daylight.

Baba-Nyonya heritage shophouse courtyard

A good biophilic design should fulfil two main dimensions, the 'organic or naturalistic' and the 'place-based or vernacular' dimensions. Hence, this study focuses only on the local edible and medicinal plants application in heritage shophouses especially in the central courtyard area. In general, shophouse can be defined as a multifunctional deep rectangular urban building, with a shop or business on the ground floor and residential on the above. It could be one or more shops in a single building (figure 1) (Wooi 2015). Shophouses are normally built-in rows with interconnecting walkway on the front, known as the 'kaki lima' or five-foot walkway. The façade is narrow, around six to seven metres wide, but it could reach up to thirty metres in length (Ahmad 1994). Due to its length, each shophouses is equipped with air-well or courtyard to control the microclimate in the building and to illuminate the interior. Courtyard is also used as a thermal barrier and for acoustic and visual privacy (Sthapak and Bandyopadhyay 2014). Traditionally, there are three important known implications in a courtyard namely the cultural, climatical, and psychological implications.

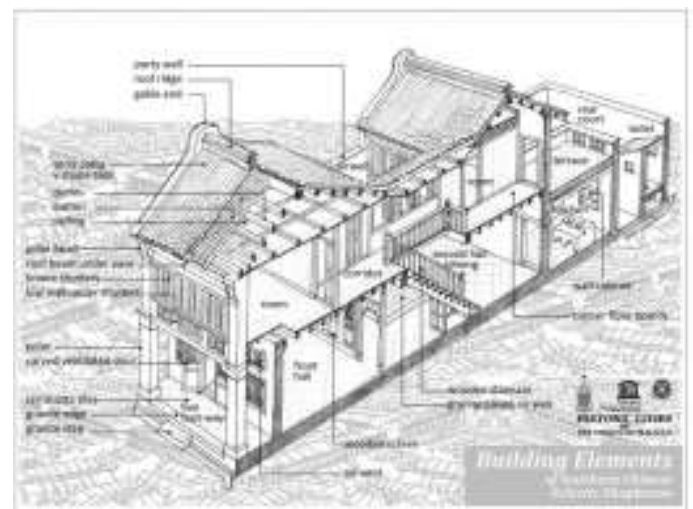

Figure 1. Axonometric view of traditional Penang shophouse

Source: (Wooi 2015)

\section{Cultural implications}

According to Knapp, Ong, and Wang (2010), courtyard (figure 2) is an architectural component that suits the local culture as well as the local society. In addition, the main courtyard is usually for family members private use only (GTWHI 2017b). Unfortunately, after George Town has been listed as the UNESCO World Heritage Site (WHS) in 2008, most of the shophouses courtyards had been altered from private into public spaces for commercial purposes. These changes could affect the authenticity of the sites and the Outstanding Universal Value (OUV) if too many unmonitored alterations being undertaken and neglecting the conservation guidelines.

\section{Climatological implications}

Courtyard, or air-well, is one of the most significant architectural features in traditional shophouse. It was designed to be fully open to the sky as a passive cooling system in the centre of the narrow and deep rear of the traditional shophouse without relying on the air conditioning system. It is a cooling source for the surrounding area of the shophouse. According to Zakaria, Kubota, and Toe (2015), the indoor temperature in the living hall and the bedroom on the first floor are $0.3-1.7^{\circ} \mathrm{C}$ lower than the outdoor air during daytime. The prevailing wind speed relatively increased during the daytime; therefore, the ventilation rate is high from both courtyards. Moreover, cross-ventilation occurred from the rear courtyard to the front courtyard. This will 
enhance the cooling effect, particularly on the ground floor. In contrary, the indoor air temperature during the night-time were $0.8-1.9^{\circ} \mathrm{C}$ higher than the outdoor

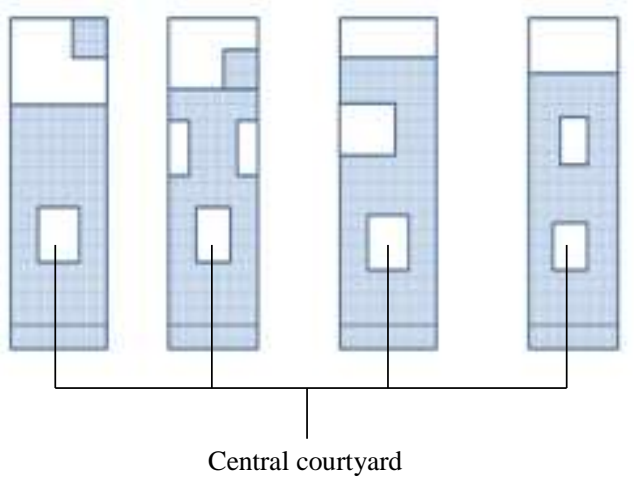

Figure 2. Central courtyard layout on different shophouse typology

Source: (GTWHI 2017a)

Plants and water elements are usually placed in the courtyard which help to increase the humidity and enhance the level of thermal comfort in tropical climate. However, since the mean air temperature has increased by $0.25^{\circ} \mathrm{C}$ per decade in the Peninsular Malaysia (NRE 2015), air conditioning system is commonly installed in the shophouses to achieve a thermally comfortable indoor environment. Tang (2019) also reported, extreme rainfalls and wind also increased for the past three decades. These conditions have initiated the shophouses owners to cover their courtyards with polycarbonate roofing to keep the courtyards dry. Other reasons include to prevent the droppings of foreign objects and to avoid the dissipating of cool air from the air conditioner system installed.

\section{Psychological implications}

Beside cultural and climatological implications, courtyard also has the psychological implications towards the occupants. Courtyard is known to provide a sense of enclosure and privacy to the residents who lived in there. It is visually obstructed by a full-height wooden screen (divider) from main entrance (Sthapak and Bandyopadhyay 2014). In the other hand, courtyard also acts as a noise absorber within the shophouse and noise barrier from outdoor. This creates a safe, quiet and private feeling for the shophouse residents. Recently, in most shophouses courtyard in George Town, it becomes an enclosed indoor public space such as café, bar, and souvenir corner.

\section{Method}

To obtain the objective, this study was carried out in the Core Zone in the UNESCO World Heritage Site (WHS) George Town, which focuses only in the Special Zone. According to the Special Area Plan, this zone is considered special because it has the strictest form of land use control. It also contains a complex layering of cultural, socioeconomic, religious, and residential morphologies (Penang State Government 2016). Within this area, there are many significant cultural sites and buildings which are listed under Category I building. Those are the buildings that are more than 50 years and officially listed in the National Heritage Act 2005, including the heritage shophouses. Most of these buildings are well-kept and lived-in by multi-cultural residents. Contemporary café is selected as case studies in this research due to their potential of using edible plants in their food menus. These cafés served fusion Malay and/or Baba-Nyonya cuisines and Western foods with local influences. The selection of the case studies was based on these criteria: (i) located in the Special Zone of the UNESCO World Heritage Site, (ii) part of heritage shophouses, (iii) the courtyards were still intact and not covered with polycarbonate sheets. Based on the criteria stipulated, there were three cafés for the study. Those are the Edelweiss Café, Armenian House Café, and Art of Dragon Gallery which were located within one area (figure 3 ). Qualitative method was used to examine and analyse the indoor plants application in shophouse courtyards using architectural observation and documentation, plant inventory and identification of the species, and followed by descriptive analysis. 


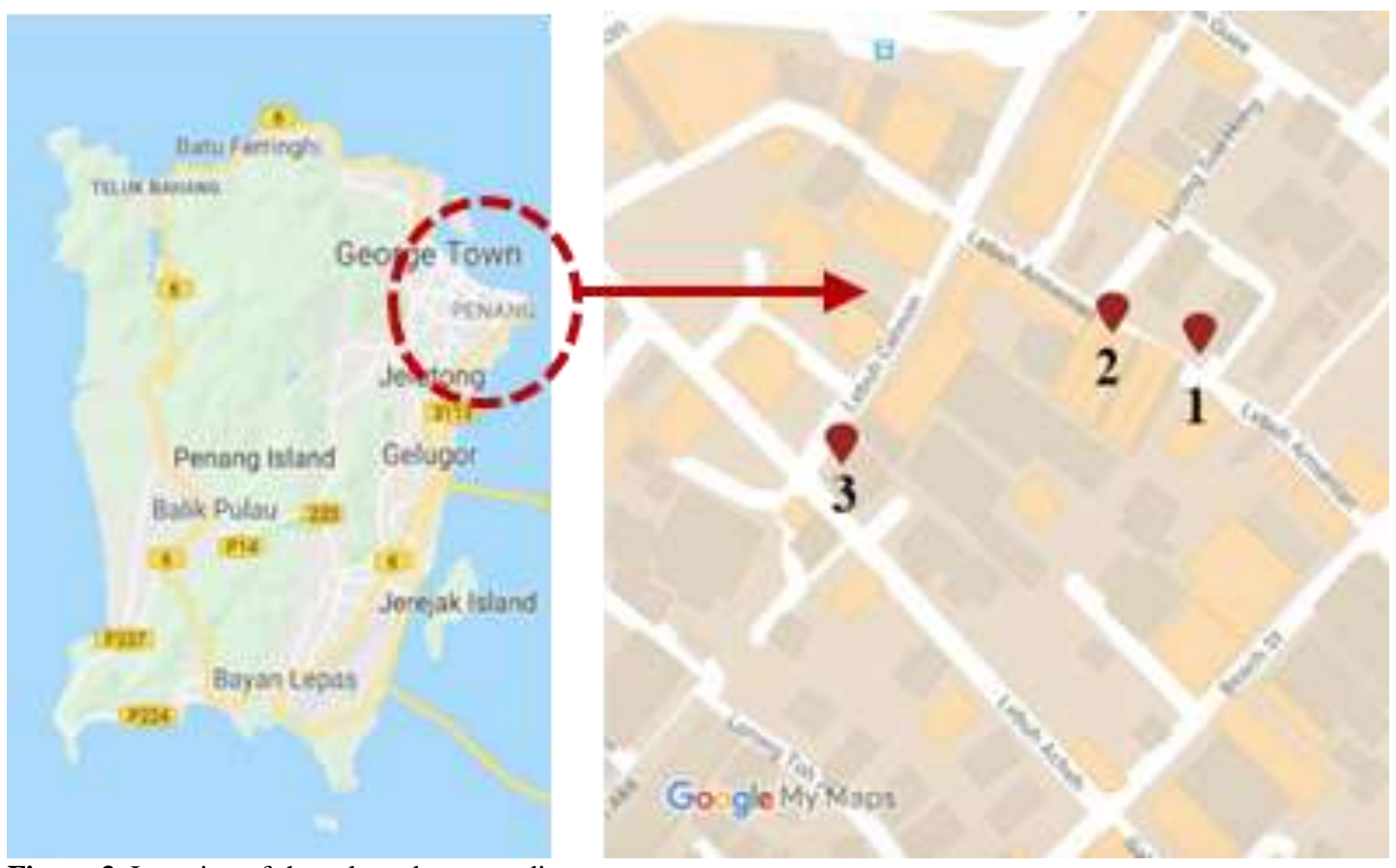

Figure 3. Location of the selected case studies

\section{Result and discussion}

Edelweiss café

Edelweiss café is a European café in a 'Southern Chinese' Eclectic Style. The building was built between the year 1840 until 1910 (figure 4a). The courtyard was well maintained and converted as a semi-outdoor dining area. The opening of the courtyard remained uncovered to allow the natural daylighting, air ventilation, and rainwater to penetrate the courtyard. Due to the security issue, metal grill was installed on the opening (figure $4 \mathrm{~b}, 4 \mathrm{c}$ ). The natural daylighting in thr courtyard brought in positive effects towards human's health, satisfaction, attention, and performance (Edwards and Torcellini 2002; Gray and Birrell 2014). It showed Biophilic Design Pattern (P6) was achieved in the courtyard. The presence of natural air ventilation in the café allowed a breezing air movement in the courtyard for a better human comfort. This has achieved the Biophilic Design Pattern (P4). On the other hand, natural materials (P9) such as wood features could be found in the courtyard. The differences in wood features and colour tones created the feeling of balance, harmony and simplicity; and it brought positive effects on human comfort and relaxation (Nyrud and Bringslimark 2010; Ikei,
Song, and Miyazaki 2017; Tsunetsugu, Miyazaki, and Sato 2007; Kelz, Grote, and Moser 2011).

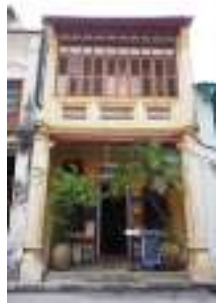

(a)

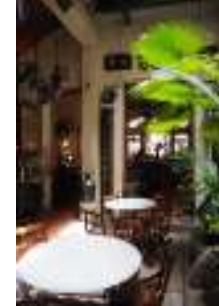

(b)

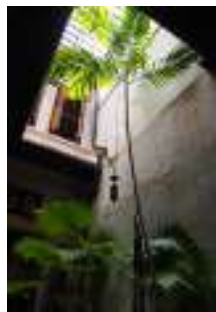

(c)
Figure 4. The façade and courtyard of Edelweiss café

Table 2. Types of plants in Edelweiss café

\begin{tabular}{|c|c|c|c|}
\hline $\begin{array}{l}\text { Scientific } \\
\text { name }\end{array}$ & $\begin{array}{l}\text { Common } \\
\text { name }\end{array}$ & Usage & $\begin{array}{l}\text { Biophilic } \\
\text { design } \\
\text { patterns }\end{array}$ \\
\hline $\begin{array}{l}\text { A. 'Dud } \\
\text { Unyamane' }\end{array}$ & $\begin{array}{l}\text { Chinese } \\
\text { evergreens }\end{array}$ & Ornamental $^{1}$ & $\begin{array}{l}\text { (P1) } \\
\text { achieved }\end{array}$ \\
\hline $\begin{array}{l}\text { A. commu- } \\
\text { tatum }\end{array}$ & $\begin{array}{l}\text { Chinese } \\
\text { evergreens }\end{array}$ & Ornamental $^{1}$ & $\begin{array}{l}\text { (P1) } \\
\text { achieved }\end{array}$ \\
\hline A. nidus & $\begin{array}{l}\text { Bird's nest } \\
\text { fern }\end{array}$ & Ornamental $^{1}$ & $\begin{array}{l}(\mathrm{P} 1) \\
\text { achieved }\end{array}$ \\
\hline $\begin{array}{l}\text { S. podo- } \\
\text { phyllum }\end{array}$ & $\begin{array}{l}\text { Arrowhead } \\
\text { plant }\end{array}$ & $\begin{array}{l}\text { Ornamental, } \\
\text { air purifier }{ }^{1,2}\end{array}$ & $\begin{array}{l}\text { (P1) } \\
\text { achieved }\end{array}$ \\
\hline $\begin{array}{l}\text { Neoregelia } \\
\text { sp. }\end{array}$ & $\begin{array}{l}\text { Blushing } \\
\text { bromeliad }\end{array}$ & Ornamental $^{1}$ & $\begin{array}{l}\text { (P1) } \\
\text { achieved }\end{array}$ \\
\hline $\begin{array}{l}\text { L. chinen- } \\
\text { sis }\end{array}$ & $\begin{array}{l}\text { Chinese } \\
\text { fan palm }\end{array}$ & Ornamental $^{1}$ & $\begin{array}{l}\text { (P1) } \\
\text { achieved }\end{array}$ \\
\hline $\begin{array}{l}\text { C. lutes- } \\
\text { cens }\end{array}$ & $\begin{array}{l}\text { Golden } \\
\text { cane palm, } \\
\text { Areca } \\
\text { palm, }\end{array}$ & $\begin{array}{l}\text { Ornamental. } \\
\text { toxic gas } \\
\text { removal, air } \\
\text { purifier }{ }^{1,2}\end{array}$ & $\begin{array}{l}\text { (P1) } \\
\text { achieved }\end{array}$ \\
\hline
\end{tabular}




\begin{tabular}{llll}
\hline $\begin{array}{l}\text { Scientific } \\
\text { name }\end{array}$ & $\begin{array}{l}\text { Common } \\
\text { name }\end{array}$ & Usage & $\begin{array}{l}\text { Biophilic } \\
\text { design } \\
\text { patterns }\end{array}$ \\
\hline & $\begin{array}{l}\text { Yellow } \\
\text { palm }\end{array}$ & \\
\hline
\end{tabular}

Source: (National Parks Board 2020ํ․ Wolverton 1996 $)^{2}$

Potted plants were also found in the courtyard with the listed of plants (table 2). The indoor plants were pure ornamental foliage plants without medicinal properties of Aglaonema 'Dud Unyamane' (Chinese evergreen), Aglaonema commutatum (Chinese evergreen), Asplenium nidus (Bird's nest fern), Syngonium podophyllum (Arrowhead plant), Neoregelia sp. (Blushing bromeliad), Livistona chinensis (Chinese fan palm), and Chrysalidocarpus lutescens (Golden cane palm) (National Parks Board 2020). According to Wolverton (1996), S. podophyllum and $C$. lutescens could act as air purifiers. The latter is effective in removing toxic gas. The presence of indoor ornamental foliage plants is merely as aesthetics to beautify the courtyard environment. The patrons were able to visually access the courtyard with relaxing and calming feeling while enhancing their biophilia experience (P1). According to Asdrubali et al. (2014) and Wolverton (1996), plants can act as sound absorbers.

Armenian house café

Armenian house café is categorised as the 'early straits' eclectic style shophouse that was built between 1890s-1920s. This shophouse was influenced by the European architecture style seen in the pilasters and other façade architectural details (figure 5a).

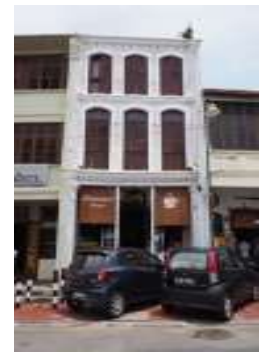

(a)

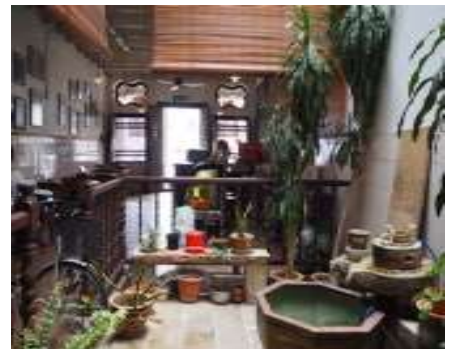

(b)
Figure 5. Façade and courtyard of Armenian house café

The courtyard was not covered in order to maximise the air circulation (P4) and the amount of natural daylighting penetration (P6). Water feature was available at the centre of the courtyard in the form of granite millstone water fountain and a mini pond made from clay vase. In Biophilic Design the presence of water (P5) created a tranquil and restoring environment through visual and auditory sound (P2) (White et al. 2010). The potted plants grown were ornamental foliage plants with Biophilic Design Pattern (P1) (figure $5 b)$ and without local edible and/or medicinal plants. Those were Chlorophytum comosum (Spider plant), Dracaena fragrans (Dracaena 'corn plant'), Echinodorus palaefolius (Mexican sword plant), Epipremnum aureum (money plant), Sansevieria trifasciata var. laurentii (Mother-in-law's tounge), Nephrolepis exaltata (Boston fern), and Dracaena reflexa (Song of India) (table 3). According to Wolverton (1996) and (National Parks Board 2020), C. comosum, D. fragrans, E. aureum, S. trifasciata var. laurentii, and $D$. reflexa are recommended to be placed in an indoor environment to purify the air. Boston fern or $N$. exaltata is also an air purifier as well as a noise absorber (Wolverton 1996; Asdrubali et al. 2014). E. palaefolius is neither the purifier nor noise absorber. In addition, the usage of timber elements in wooden blinds and wooden balusters were seen surrounding the courtyard (P9).

Table 3. Types of plants in Armenian house café

\begin{tabular}{|c|c|c|c|}
\hline $\begin{array}{l}\text { Scientific } \\
\text { name }\end{array}$ & $\begin{array}{l}\text { Common } \\
\text { name }\end{array}$ & Usage & $\begin{array}{l}\text { Biophilic } \\
\text { design } \\
\text { patterns }\end{array}$ \\
\hline $\begin{array}{l}\text { C. } \\
\text { comosum }\end{array}$ & $\begin{array}{l}\text { Spider } \\
\text { plant }\end{array}$ & $\begin{array}{l}\text { Ornamental, Air } \\
\text { purifier }^{1}\end{array}$ & $\begin{array}{l}\text { (P1) } \\
\text { achieved }\end{array}$ \\
\hline D. fragrans & $\begin{array}{l}\text { Dracaena } \\
\text { corn plant }\end{array}$ & $\begin{array}{l}\text { Ornamental, Air } \\
\text { purifier }^{1}\end{array}$ & $\begin{array}{l}(\mathrm{P} 1) \\
\text { achieved }\end{array}$ \\
\hline $\begin{array}{l}E . \\
\text { palaefolius }\end{array}$ & $\begin{array}{l}\text { Mexican } \\
\text { sword } \\
\text { plant }\end{array}$ & Ornamental $^{3}$ & $\begin{array}{l}\text { (P1) } \\
\text { achieved }\end{array}$ \\
\hline E. aureum & $\begin{array}{l}\text { Golden } \\
\text { pothos, } \\
\text { Money } \\
\text { plant }\end{array}$ & $\begin{array}{l}\text { Ornamental, Air } \\
\text { purifier }^{1}\end{array}$ & $\begin{array}{l}(\mathrm{P} 1) \\
\text { achieved }\end{array}$ \\
\hline $\begin{array}{l}\text { S. } \\
\text { trifasciata } \\
\text { var. } \\
\text { laurentii }\end{array}$ & $\begin{array}{l}\text { Snake } \\
\text { plant, } \\
\text { Mother-in- } \\
\text { law's } \\
\text { tongue }\end{array}$ & $\begin{array}{l}\text { Ornamental, Air } \\
\text { purifier }^{1}\end{array}$ & $\begin{array}{l}(\mathrm{P} 1) \\
\text { achieved }\end{array}$ \\
\hline N. exaltata & $\begin{array}{l}\text { Boston } \\
\text { fern }\end{array}$ & $\begin{array}{l}\text { Ornamental, air } \\
\text { purifier, noise } \\
\text { absorber }^{1,2}\end{array}$ & $\begin{array}{l}(\mathrm{P} 1) \\
\text { achieved }\end{array}$ \\
\hline D. reflexa & $\begin{array}{l}\text { Song of } \\
\text { India }\end{array}$ & $\begin{array}{l}\text { Ornamental, air } \\
\text { purifier }^{1}\end{array}$ & $\begin{array}{l}\text { (P1) } \\
\text { achieved }\end{array}$ \\
\hline
\end{tabular}

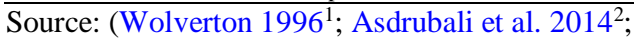

National Parks Board 2020) ${ }^{3}$

Art of Dragon gallery

This café is situated within a row of 'Southern Chinese' Eclectic Style shophouses. This building was built between the year 1840 until 1910 . 
Compare to the previous case study, this café had a minimum conservation work. This could be seen from the condition of the façade and the courtyard (figure 6a-c). In this café, the courtyard remained not covered; therefore, the daylight, outdoor air, and rainwater could penetrate the courtyard naturally (figure 6c). Thus, Biophilic Design Patterns Thermal and Airflow Variability (P4), and Dynamic and Diffuse Light (P6) were achieved coupled with a mini portable water cascade in the courtyard (P5). The courtyard had a combination of ornamental foliage, artificial, and edible plants (P1) (table 4). The indoor plants observed in the courtyard were a combination of life and artificial plants (figure $6 \mathrm{~b}, \mathrm{c}$ ). The plants were grown in pots for easy maintenance and cost-saving. The life plants were Pandanus amaryllifolius (Pandan leaf), S. podophyllum (Arrowhead plant), and one unidentified ornamental plant. There were also artificial plants in the courtyard that looked like water lily in pond and creepers on the wall. Based on the information given by the proprietor, $P$. amaryllifolius was purposely grown as an ingredient for their signature beverage; and for colouring and flavouring of desserts and cakes and having medicinal properties (Nor et al. 2008). It is proven as a natural pest repellent, anti-virus, antioxidant, anti-diabetic, anti-hyperglycaemic, and anti-rheumatism (National Parks Board 2020; Saenthaweesuk, Naowaboot, and Somparn 2016). Hence, this plant was not only contributed to Biophilic Design Pattern (P1), but also Biophilic Design Pattern (P2) through other human senses of smell, touch and taste.

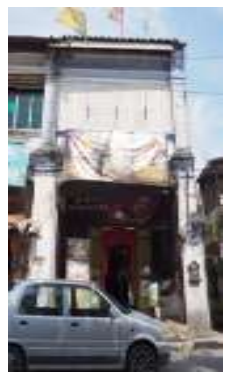

(a)

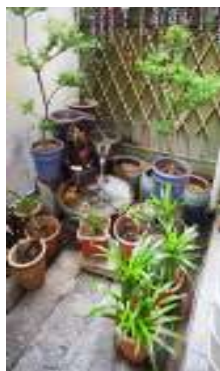

(b)

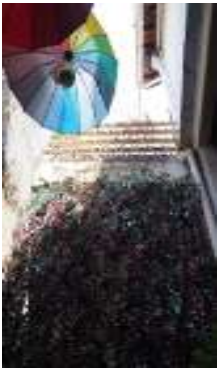

(c)
Figure 6. Façade and courtyard of Art of Dragon gallery
Table 4. Types of plants in Art of Dragon gallery

\begin{tabular}{|c|c|c|c|}
\hline $\begin{array}{l}\text { Scientific } \\
\text { name }\end{array}$ & $\begin{array}{l}\text { Common } \\
\text { name }\end{array}$ & Usage & $\begin{array}{l}\text { Biophilic } \\
\text { design } \\
\text { patterns }\end{array}$ \\
\hline $\begin{array}{l}\text { P. amaryl- } \\
\text { lifolius }\end{array}$ & $\begin{array}{l}\text { Pandan } \\
\text { leaf }\end{array}$ & $\begin{array}{l}\text { Food colour, } \\
\text { fragrance, } \\
\text { medicinal }^{2}\end{array}$ & $\begin{array}{l}\text { a. (P1) } \\
\text { achieved. } \\
\text { b. (P2) } \\
\text { achieved. }\end{array}$ \\
\hline $\begin{array}{l}\text { S. podophyl- } \\
\text { lum }\end{array}$ & $\begin{array}{l}\text { Arrowhead } \\
\text { plant }\end{array}$ & $\begin{array}{l}\text { Ornamental, } \\
\text { air purifier }{ }^{1}\end{array}$ & $\begin{array}{l}\mathrm{P} 1) \\
\text { achieved }\end{array}$ \\
\hline Nymphaeaceae & $\begin{array}{l}\text { Water } \\
\text { lilies }\end{array}$ & $\begin{array}{l}\text { Medicinal, } \\
\text { ornamental, } \\
\text { ritual and } \\
\text { ceremony } \\
\text { material }{ }^{3,4}\end{array}$ & $\begin{array}{l}\mathrm{P} 1) \\
\text { achieved }\end{array}$ \\
\hline E. aureum & $\begin{array}{l}\text { Golden } \\
\text { pothos, } \\
\text { Money } \\
\text { plant }\end{array}$ & $\begin{array}{l}\text { Ornamental, } \\
\text { air purifier }{ }^{1}\end{array}$ & $\begin{array}{l}\text { (P1) } \\
\text { achieved }\end{array}$ \\
\hline $\begin{array}{l}\text { S. trifasciata } \\
\text { var. laurentii }\end{array}$ & $\begin{array}{l}\text { Snake } \\
\text { plant, } \\
\text { Mother-in- } \\
\text { law's } \\
\text { tongue }\end{array}$ & $\begin{array}{l}\text { Ornamental, } \\
\text { air purifier }{ }^{1}\end{array}$ & $\begin{array}{l}\text { (P1) } \\
\text { achieved }\end{array}$ \\
\hline N. exaltata & $\begin{array}{l}\text { Boston } \\
\text { fern }\end{array}$ & $\begin{array}{l}\text { Ornamental, } \\
\text { air purifier, } \\
\text { noise } \\
\text { absorber }^{1,2}\end{array}$ & $\begin{array}{l}\text { (P1) } \\
\text { achieved }\end{array}$ \\
\hline D. reflexa & $\begin{array}{l}\text { Song of } \\
\text { India }\end{array}$ & $\begin{array}{l}\text { Ornamental, } \\
\text { air purifier }\end{array}$ & $\begin{array}{l}\text { (P1) } \\
\text { achieved }\end{array}$ \\
\hline
\end{tabular}

Source: (Wolverton 1996 ${ }^{1}$; Nor et al. 2008²; De

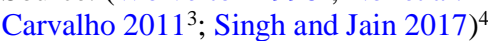

\section{Conclusion}

There were six types of Biophilic Design Patterns found in the case studies. With the combination of Biophilic Design Pattern (P4) and (P6), it enabled the indoor plants to be grown well in the courtyards. Most of these plants served for ornamental purposes to beautify the indoor environment and to flourish human well-being through visual connection with nature (P1). Seven out of fifteen life indoor plants functioned as indoor air purifiers. Only P. amarylifolius, or pandan leaf, was edible, grown in courtyards of the cafés; and categorised as herb. It could be concluded that the presence of local knowledge of edible plants in heritage shophouse courtyard was not extensive. In Malaysia, the sun shines throughout the year allowing the planting of edible and medicinal plants. Moreover, the climatic condition in the courtyards of the chosen Baba-Nyonya heritage shophouses were suitable for the semi-outdoor and indoor plants. Hence, the courtyards could become the alternative green spaces integrating with the buildings. Growing plants on the five-foot walkway is discouraged by the local authority since it will obstruct public activities and circulation. By having plants in the building, the regularity of maintenance needs to 
be considered to obtain the maximum benefits from the plants. In-depth study on the BabaNyonya local knowledge of edible and medicinal plants suitable for the indoor and semi-outdoor environments is further required. These plants are important to enhance human well-being in indoor environment, to improve the indoor air quality, as well as to provide herbs, foods, and traditional medicine at domestic level.

\section{Acknowledgment}

The research was fully funded by Universiti Sains Malaysia and the School of Housing, Building and Planning through the FRGS Grant 203/PPBGN/6711519 with the support of the Fellowship Scheme of Institute of Postgraduate Studies, USM. Sustainable Development Goals (SDG): Human Settlement and Cultural Heritage.

\section{References}

Ahmad, A. Ghafar. 1994. The Architectural Style of the Peranakan Cina. Malaysia: Universiti Sains Malaysia.

Asdrubali, Francesco, Nicholas Mencarelli, Kirill V. Horoshenkov, and Francesco D’Alessandro. 2014. 'Sound Absorption Properties of Tropical Plants for Indoor Applications'. In The 21st International Congress on Sound and Vibration. Beijing, China.

Bringslimark, Tina, Terry Hartig, and Grete Grindal Patil. 2007. 'Psychological Benefits of Indoor Plants in Workplaces: Putting Experimental Results into Context'. HortScience $\quad 42 \quad$ (3): $\quad 581-87$. https://doi.org/10.21273/HORTSCI.42.3.581.

Burchett, Margaret, Fraser Torpy, and Jane Tarran. 2008. 'Interior Plants for Sustainable Facility Ecology and Workplace Productivity'. Academmia.Edu. 2008.

C. H., Ong, Norliah A., and Sorayya M. 2012. 'Traditional Knowledge and Usage of Edible Plants among the Temuan Villagers in Kampung Tering, Kuala Pilah, Negeri Sembilan, Malaysia'. Indian Journal of Traditional Knowledge 11 (1): 161-65. http://nopr.niscair.res.in/bitstream/123456789 /13428/1/IJTK 11\%281\%29 161-165.pdf.

Carvalho, Luís Manuel Mendoncça De. 2011. 'The Symbolic Uses of Plants'. In Ethnobiology, 351-69. Hoboken, NJ, USA: John Wiley \& Sons, Inc. https://doi.org/10.1002/9781118015872.ch21

D’Alessandro, Francesco, Francesco Asdrubali, and Nicholas Mencarelli. 2015. 'Experimental Evaluation and Modelling of the Sound Absorption Properties of Plants for Indoor Acoustic Applications'. Building and Environment 94 (December): 913-23. https://doi.org/10.1016/j.buildenv.2015.06.00 4.

Edwards, L., and P. Torcellini. 2002. 'Literature Review of the Effects of Natural Light on Building Occupants'. Golden, CO. https://doi.org/10.2172/15000841.

Fjeld, Tove, and Charite Bonnevie. 2002. 'The Effect of Plants and Artifical Day-Light on the Well-Being and Health of Office Workers, School Children and Health Care Personnel'. In Reducing Heath Complaints at Work Plants for People, 1-10. Floriade: Int. Hort. Exhib.

Gray, Tonia, and Carol Birrell. 2014. 'Are Biophilic-Designed Site Office Buildings Linked to Health Benefits and High Performing Occupants?' International Journal of Environmental Research and Public Health 11 (12): 12204-22. https://doi.org/10.3390/ijerph111212204.

GTWHI. 2017a. 'Introduction to Heritage and Conservation'. Penang, Malaysia.

. 2017b. 'Traditional Shophouses 'Building Typology'.

Ikei, Harumi, Chorong Song, and Yoshifumi Miyazaki. 2017. 'Physiological Effects of Wood on Humans: A Review'. Journal of Wood Science 63 (1): 1-23. https://doi.org/10.1007/s10086-016-1597-9.

Jumeno, Desto, and Hiroshi Matsumoto. 2015. 'Effects of Foliage Plants on Human Physiological and Psychological Responses at Different Temperatures'. In , 32-40. https://doi.org/10.1063/1.4913541.

Karima, Miftahul, Yohannes Firzal, and Gun Faisal. 2020. 'Penerapan Prinsip Desain Arsitektur Biofilik Pada Riau Mitigation and Disaster Management Center'. ARTEKS: 
Jurnal Teknik Arsitektur 5 (2): 307-16. https://doi.org/10.30822/arteks.v5i2.448.

Kellert, Stephen R. 2008. 'Dimensions, Elements and Attributes of Biophilic Design'. In Biophilic Design: The Theory, Science and Practice of Bringing Buildings to Life, edited by Stephen R. Kellert, Judith H. Heerwagen, and Martin L. Mador. New York: John Wiley $\&$ Sons, Inc.

Kelz, Christina, Vincent Grote, and Maximilian Moser. 2011. 'Interior Wood Use in Classrooms Reduces Pupils' Stress Levels'. In 9th Biennial Conference on Environmental Psychology. Eindhoven, The Netherlands: Environment and Health.

Knapp, R., A. Ong, and G. Wang. 2010. Chinese Houses of Southeast Asia: The Eclectic Architecture of Sojourners and Settlers. United States of America: Tuttle Publishing.

Larsen, Larissa, Jeffrey Adams, Brian Deal, Byoung Suk Kweon, and Elizabeth Tyler. 1998. 'Plants in the Workplace'. Environment and Behavior 30 (3): 261-81. https://doi.org/10.1177/00139165980300030 1.

Lee, Min-sun, Juyoung Lee, Bum-Jin Park, and Yoshifumi Miyazaki. 2015. 'Interaction with Indoor Plants May Reduce Psychological and Physiological Stress by Suppressing Autonomic Nervous System Activity in Young Adults: A Randomized Crossover Study'. Journal of Physiological Anthropology $34 \quad$ (1): 21. https://doi.org/10.1186/s40101-015-0060-8.

Leipzig. 1996. 'Malaysia: Country Report to The Fao International Technical Conference on Plant Genetic Resources'. Kuala Lumpur.

Lohr, V.I. 2010. 'What Are The Benefit of Plants Indoors and Why Do We Respond Positively to Them?' Acta Horticulturae, no. 881 (November): $\quad 675-82$. https://doi.org/10.17660/ActaHortic.2010.88 1.111.

Milow, Pozi, Sorayya Bibi Malek, Juli Edo, and Hean-Chooi Ong. 2014. 'Malaysian Species of Plants with Edible Fruits or Seeds and Their Valuation'. International Journal of Fruit Science $\quad 14 \quad$ (1): $1-27$. https://doi.org/10.1080/15538362.2013.8016 98.

National Parks Board. 2020. 'National Parks Board 2020'. NParks Flora \& Fauna Web: A Singapore Government Agency Website. 2020. https://www.nparks.gov.sg/florafaunaweb/ab out-us.

Nor, Fatihanim Mohd, Suhaila Mohamed, Nor Aini Idris, and Razali Ismail. 2008. 'Antioxidative Properties of Pandanus Amaryllifolius Leaf Extracts in Accelerated Oxidation and Deep Frying Studies'. Food $\begin{array}{lll}\text { Chemistry } & 110 & \text { (2): }\end{array}$ https://doi.org/10.1016/j.foodchem.2008.02.0 04.

NRE. 2015. 'Malaysia Biennial Update Report to the UNFCC'. Malaysia. https://unfccc.int/documents/180659.

Nyrud, Anders Q., and Tina Bringslimark. 2010. 'Is Interior Wood Use Psychologically Beneficial? A Review of Psychological Responses toward Wood'. Wood and Fiber Science 42 (202-218). https://wfs.swst.org/index.php/wfs/article/vie wFile/1365/1365.

Orians, Gordon H., and Judith H Heerwagen. 1992. 'Evolved Responses to Landscapes'. In The Adapted Mind: Evolutionary Psychology and the Generation of Culture, edited by J. H. Barkow, L. Cosmides, and J. Tooby, 555-79. New York: Oxford University Press.

Penang State Government. 2016. 'Special Area Plan: George Town Historic Cities of the Straits of Malacca'. Penang, Malaysia.

Piko, Bettina F. 2006. 'Burnout, Role Conflict, Job Satisfaction and Psychosocial Health among Hungarian Health Care Staff: A Questionnaire Survey'. International Journal of Nursing Studies 43 (3): 311-18. https://doi.org/10.1016/j.ijnurstu.2005.05.003

Prihatmanti, Rani, and Azizi Bahauddin. 2014. 'Indoor Air Quality in Adaptively Reused Heritage Buildings at a UNESCO World Heritage Site, Penang, Malaysia'. Journal of Construction in Developing Countries 19 (1).

Prihatmanti, Rani, and Nooriati Taib. 2018. 'Multi-Layer Planting as a Strategy of Greening the Transitional Space in High-Rise Buildings: A Review'. IOP Conference Series: Earth and Environmental Science 126 (March):

012013. https://doi.org/10.1088/17551315/126/1/012013.

Ryan, Catherine O., William D Browning, Joseph O Clancy, Scott L Andrews, and Namita B Kallianpurkar. 2014. 'BIOPHILIC DESIGN PATTERNS: Emerging Nature-Based Parameters for Health and Well-Being in the 
Built Environment'. International Journal of Architectural Research: ArchNet-IJAR 8 (2): 62. https://doi.org/10.26687/archnetijar.v8i2.436.

Saenthaweesuk, Suphaket, Jarinyaporn Naowaboot, and Nuntiya Somparn. 2016. 'Pandanus Amaryllifolius Leaf Extract Increases Insulin Sensitivity in High-Fat DietInduced Obese Mice'. Asian Pacific Journal of Tropical Biomedicine 6 (10): 866-71. https://doi.org/10.1016/j.apjtb.2016.08.010.

Salleh, Ismail Hafiz, Mohd Sabrizaa Abd. Rashid, and Siti Rasidah Md Sakip. 2016. 'Malay Garden Concept from the Traditional Malay Landscape Design'. Procedia - Social and Behavioral Sciences 222 (June): 548-56. https://doi.org/10.1016/j.sbspro.2016.05.213.

Samy, Joseph, M. Sugumaran, and Kate L. W. Lee. 2014. 100 Useful Herbs of Malaysia and Singapore. Edited by K. M. Wong. Singapore: Marshall-Cavendish Editions.

Shibata, Seiji, and Naoto Suzuki. 2004. 'Effects of an Indoor Plant on Creative Task Performance and Mood'. Scandinavian Journal of Psychology 45 (5): 373-81. https://doi.org/10.1111/j.14679450.2004.00419.x.

Singh, Manjeet, and Alok Pal Jain. 2017. 'A Review on Genus Nymphaea: Multi-Potential Medicinal Plant'. Asian Journal of Pharmaceutical Education and Research 6 (4): $1-9$. http://ajper.com/admin/assets/article_issue/15 08169483.pdf.

Sthapak, Swasti, and Abir Bandyopadhyay. 2014. 'Courtyard Houses: An Overview'. Recent Research in Science and Technology 6 (1): 70-73.

Tang, Kuok Ho Daniel. 2019. 'Climate Change in Malaysia: Trends, Contributors, Impacts, Mitigation and Adaptations'. Science of The Total Environment 650 (February): 1858-71. https://doi.org/10.1016/j.scitotenv.2018.09.31 6.

Tsunetsugu, Yuko, Yoshifumi Miyazaki, and Hiroshi Sato. 2007. 'Physiological Effects in Humans Induced by the Visual Stimulation of Room Interiors with Different Wood Quantities'. Journal of Wood Science 53 (1):
11-16. https://doi.org/10.1007/s10086-0060812-5.

Ulrich, Roger S., Robert F. Simons, Barbara D. Losito, Evelyn Fiorito, Mark A. Miles, and Michael Zelson. 1991. 'Stress Recovery during Exposure to Natural and Urban Environments'. Journal of Environmental $\begin{array}{llll}\text { Psychology } & 11 & \text { (3): } 201-30 .\end{array}$ https://doi.org/10.1016/S02724944(05)80184-7.

White, Mathew, Amanda Smith, Kelly Humphryes, Sabine Pahl, Deborah Snelling, and Michael Depledge. 2010. 'Blue Space: The Importance of Water for Preference, Affect, and Restorativeness Ratings of Natural and Built Scenes'. Journal of Environmental Psychology $30 \quad$ (4): $\quad 482-93$. https://doi.org/10.1016/j.jenvp.2010.04.004.

Widodo, Johannes. 2019. 'Human, Nature, And Architecture'. ARTEKS: Jurnal Teknik Arsitektur 3 (2): 145-48. https://doi.org/10.30822/arteks.v3i2.65.

Wilson, E. O. 1984. Biophilia: The Human Bond with Other Species. Cambridge, MA: Hardvard University Press.

Wolverton, Dr. B.C. 1996. How to Grow Fresh Air. London, United Kingdom: Penguin Group.

Wooi, Tan Yeow. 2015. Penang Shophouses: A Handbook of Features and Materials. 1st ed. George Town: Tan Yeow Wooi Culture and Research Studio.

Zakaria, Mohd Azuan, Tetsu Kubota, and Doris Hooi Chyee Toe. 2015. 'The Effects of Courtyards on Indoor Thermal Conditions of Chinese Shophouse in Malacca'. Procedia Engineering 121: 468-76. https://doi.org/10.1016/j.proeng.2015.08.109 4.

\section{Author(s) contribution}

Azizi Bahauddin contributed to the research concepts preparation, methodologies, investigations, data analysis, visualization, articles drafting and revisions.

Rani Prihatmanti contribute to methodology, supervision, and validation.

Josphine Ong contribute to methodology, supervision, and validation. 